\title{
LABORATORY AND FIELD EVALUATION OF INSECTICIDES AGAINST THE OLIVE BARK BEETLE Phloeotribus scarabaeoides Bern. (COLEOPTERA: SCOLYTIDAE) IN FAYOUM, EGYPT.
}

\author{
Rabie, H.A. Solaiman, * and Nadia, A. Abd El-latif, ** \\ * Department of Plant Protection, Faculty of Agriculture, Fayoum University \\ **Plant Protection Research Institute. A.R.C., Ministry of Agriculture.
}

\begin{abstract}
Under laboratory conditions depending on the exit holes, Cidial L50\% was the most effective insecticide at 200 and $400 \mathrm{~cm}^{3} / 100$ Lwater. Basodin $60 \%$ at $300 \mathrm{~cm}^{3} / 100$ Lwater was the most effective. The least effective was Keiton L $50 \%$ at 200,300 and $400 \mathrm{~cm}^{3} / 100$ Lwater. The highest percent reduction in number of holes was recorded for Cidial L50\% treatment $(42.43 \%)$ at $400 \mathrm{~cm}^{3} / 100 \mathrm{Lwater}$ concentration. Also results showed that Keiton L 50\% was the least effective in reducing the number of emerged beetles while both Basodin and Cidial L50\% were similarly reduced the number of beetles emerged under laboratory conditions.

Application of insecticides considerably affected parasitoids emergence with Cidial L50\% at 200 and $400 \mathrm{~cm}^{3} / 100$ Lwater only 4.17 4.33 individuals/one cutting were found compared with 34.17 parasitoids from untreated one cutting. No parasitoids were found with the use of Basodin $60 \%$. Therefore, Cidial L or Basodin; $400 \mathrm{~cm}^{3} / 100 \mathrm{~L}$ water are recomended in case of severe infestation by the scolytid $P$. scarabaeoides on olive trees.

Under field conditions, the use of Cidial L50\% and Basodin $60 \%$ EC against the olive bark beetle $P$. scarabaeoides reduced the number of inside holes by 38.52 and $19.44 \%$, respectively Cidial L50\% increased efficacy was due to its repelling effect. However, Basodin $60 \%$ EC was more effective in reducing the number of beetles emerged, due to higher mortality of beetles in maternal galleries of olive branches. Statistical analysis indicated no significant difference between the two tested insecticides.
\end{abstract}

Key words: Olive trees, Phloeotribus scarabaeoides, Cidial L50\%, Basodin $60 \%$, Keiton L 50\%, insecticides, parasitoids.

\section{INTRODUCTION}

The Scolytid bark beetle, Phloeotribus scarabaeoides (Bern.) attacks a number of different tree species including Phyllirrea, Fraxinus, Ligustrum, Syringa and olive, Olea europaea throughout the Mediterranean region (Arambourg 1986), and was recorded in Egypt by Taher, 1966 on olive trees at Matrouh. This pest is now widely distributed all over Egypt, and considered as a serious pest that attacks small branches, twigs and stems; causing death of small branches and weakening of the whole tree.

$P$. scarabaeoides are almost present all year round especially in neglected trees weakened by diseases, drought, excess watering, or infested by other pests such as Zeuzera pyrina. Detached branches especially those lying

Fayoum J. Agric. Res. \& Dev., Vol.22, No.2, July, 2008 
on the ground also attract $P$. scarabaeoides (Mostafa et al. 1992). In Jordan Mustafa and El-Mazraawi, 1996 showed that $P$. scarabaeoides is highly attracted to the branches located inside the tree canopy and against the tree main trunk after two weeks of branches cut.

Control methods include: a) plastic sheeting to cover stacks of pruned branches to trap new adults (Lanari, 1980 in Italy); b) natural balance established due to the lack of chemical treatment (Yatla, 1983 in Turkey); or c) the use of triazophos at $100 \mathrm{~g}$, isofenphos at $150 \mathrm{~g}$ and azinphos-ethyl at $400 \mathrm{~g} / \mathrm{hl}$, and deltamethrin at $100 \mathrm{~g} / \mathrm{hl}$ (Mussche et al. 1987 in Tunisia). The present study aimed to evaluate some selected insecticides against the olive bark beetle $P$. scarabaeoides. For this purpose, Cidial L50\%, Basodin 60\% EC and Keiton L 50\% were tested in the laboratory. Cidial L50 \% and Basodin $60 \%$ EC were also tested under field conditions.

\section{MATERIALS AND METHODS:}

1- Laboratory experiment: three insecticides (Cidial L50\%, Basodin 60\%EC and Keiton L50\%) with three concentrations of each; 200, 300 and 400 $\mathrm{cm}^{3} / 100$ Lwater were used in addition to application of water alone as control. Olive branches infested with $P$. scarabaeoides were collected from newly infested trees during March 2005 from Ibshawai district, Fayoum governorate. Branches were cut in the laboratory to $25 \mathrm{~cm}$. long $\mathrm{x}$ $5 \mathrm{~cm}$. dia. pieces that were examined to mark and record the number of inside holes. Each 6 cuttings (replicates) were sprayed with one of insecticide concentration chosen and left to dry, then kept in a jar $30 \mathrm{~cm}$ height, tightly covered by muslin cloth and rubber bands, and kept under laboratory conditions. Six cuttings were used as control. The cuttings were examined weekly till the end of experiment to count the number of exit holes representing number of emerged adults of the pest and the associated parasitoids. Percentage of reduction was estimated for each insecticide.

2 - Field experiment: Cidial L50\% and Basodin 60\% EC at the concentration recommended by the Ministry of agriculture $\left(300 \mathrm{~cm}^{3} / 100 \mathrm{~L}\right.$ water) were used in Nov. 27, 2005. This experiment was done at Ibshawai district, Fayoum governorate. Eighteen cuttings, $25 \mathrm{~cm}$. long and $5 \mathrm{~cm}$. dia., were taken from infested branches. All cuttings were initially examined to mark and count the inside holes due to infestation. Six cuttings (replicates) were used as check treatment, sprayed with water and the other twelve were sprayed with $500 \mathrm{~cm}^{3}$ of $300 \mathrm{~cm}^{3} / 100 \mathrm{~L}$ water concentration; 6cuttings (replicates) for each of the two materials chosen. After spraying, the cuttings were left in the farm for two months and examined weekly for new inside holes, and date of first exit holes of adults, and associated parasitoids. Cuttings were transferred to the laboratory to record the number of exit holes and parasitoids weekly for 8 weeks. These holes represented numbers of emerged adults of the pest and parasitoids. Then percentage of reduction was estimated.

Statistical analysis: Numbers of emerged beetles were computed according to the general linear models. Significant differences between treatment means were calculated by Duncan test at P0.05. using SPSSv8.0 computer program.

Fayoum J. Agric. Res. \& Dev., Vol.22, No.2, July, 2008 


\section{RESULTS AND DISCUSSION: \\ 1 - Laboratory experiment}

The effect of three selected insecticides (Cidial L50\%, Basodin 60\% and Keiton L 50\%) with three concentrations $\left(200,300\right.$ and $400 \mathrm{~cm}^{3} / 100$ Lwater) in the laboratory on olive bark beetle $P$. scarabaeoides was shown in table 1 . Data indicated that all tested insecticide treatments were insignificantly different. Depending on the exit hole reduction, Cidial L50\% was the most effective at 200 and $400 \mathrm{~cm}^{3} / 100 \mathrm{Lw}$ ater (19.21 and 17.46 exit holes/one inside hole, respectively) followed by Basodin 60\% (21.51 and 19.21exit holes/one inside hole, respectively). Basodin $60 \%$ at $300 \mathrm{~cm}^{3} / 100 \mathrm{~L}$ water was the most effective. The least effective at 200,300 and $400 \mathrm{~cm}^{3} / 100 \mathrm{~L}$ water was Keiton L 50\% (25.37, 23.95 and 21.78 exit holes/one inside hole, respectively).

Table (1): Mean numbers of emerged $P$. scarabaeoides beetles and its parasites (per one cutting) treated with insecticides under laboratory conditions.

\begin{tabular}{|c|c|c|c|c|c|c|}
\hline \multirow[t]{2}{*}{$\begin{array}{c}\text { Concentration } \\
\text { /100LW }\end{array}$} & \multirow[t]{2}{*}{ Insecticide } & \multirow[t]{2}{*}{$\begin{array}{l}\text { Pretreatment } \\
\text { insideholes }\end{array}$} & \multicolumn{2}{|c|}{$\begin{array}{l}\text { Post treatment } \\
\text { Exitholes per }\end{array}$} & \multirow[t]{2}{*}{$\begin{array}{c}\% \\
\text { Reduction }\end{array}$} & \multirow[t]{2}{*}{$\begin{array}{c}\text { Parasitoids } \\
\text { cutting }\end{array}$} \\
\hline & & & Cutting & Insidehole & & \\
\hline \multirow[t]{3}{*}{$200 \mathrm{~cm}^{3}$. } & Cidial L 50\% & 21.00 & 444.997 & 21.19 & 30.14 & 4.17 \\
\hline & Basodin 60\% EC & 20.33 & 437.33 & 21.51 & 29.08 & 0.00 \\
\hline & Keiton L 50\% & 18.00 & 456.67 & 25.37 & 16.35 & 0.00 \\
\hline \multirow{3}{*}{$300 \mathrm{~cm}^{3}$} & Cidial L 50\% & 21.50 & 418.996 & 19.49 & 35.74 & 0.17 \\
\hline & Basodin 60\% EC & 20.83 & 403.332 & 19.36 & 36.17 & 0.00 \\
\hline & Keiton L 50\% & 20.50 & 491.00 & 23.95 & 21.04 & 0.67 \\
\hline \multirow{4}{*}{$400 \mathrm{~cm}^{3}$} & Cidial L 50\% & 20.50 & 357.89 & 17.46 & 42.43 & 4.33 \\
\hline & Basodin 60\% EC & 18.67 & 358.67 & 19.21 & 36.67 & 0.00 \\
\hline & Keiton L 50\% & 20.50 & 446.499 & 21.78 & 28.19 & 0.67 \\
\hline & Control & 21.83 & 662.17 & 30.33 & - & 34.17 \\
\hline
\end{tabular}

In general, the rate of reduction increased gradually with the increase of concentration for the three tested insecticides. On the other hand, the highest reduction percentage was recorded for Cidial L50\% treatment $(42.43 \%)$ for $400 \mathrm{~cm}^{3} / 100$ Lwater concentration (table 1).

Statistical analysis indicated that $200 \mathrm{~cm}^{3} / 100 \mathrm{~L}$ water for the tested application insecticides (Cidial L $50 \%$, Basodin 60\% and Keiton L 50\%) gave the least effect on number of emerged beetles $P$. scarabaeoides. At concentration $300 \mathrm{~cm}^{3} / 100 \mathrm{~L}$ water, no significant differences were found between the tested insecticides. But were significantly different from control. Also, no significant difference between Keiton L50\% insecticide and control. As well as, at $400 \mathrm{~cm}^{3} / 100 \mathrm{~L}$ water, between the tested insecticides. A significant differences was found between this concentration and control for all insecticides but with no significant difference between Keiton L 50\% insecticide and control under laboratory conditions. Keiton L 50\% was the least effective insecticides in reducing the number of emerged beetles $P$. scarabaeoides while both Basodin $60 \%$ and Cidial L 50\% insecticides were similar in this effect.

Fayoum J. Agric. Res. \& Dev., Vol.22, No.2, July, 2008 
The most abundant parasitoids for $P$. scarabaeoides were Cheiropachus quadrum and Rhaphitelus maculatus, in addition to 2 other unidentified species founding few numbers throughout the period of experiments (March until May).

In this respect, in Egypt, Ismail et al. 1988 recorded several ectoprepupal and pupal hymenopteran parasitoids of $P$. scarabaeoides: the pteromalids, Cerocaephala corniger, Cheiropachus quadrum, Rhaphitelus maculatus, the encyrtid Litomadtix truncatellus (Copidosoma truncatellum), Eupelmus sp. and Eurytoma sp. In Spain, Campos and Lozano 1994 and Lozano et al. 2000 fond that Cheiropachus quadrum and Dendrosoter protuberanus are the main parasitoids of the olive P. scarabaeoides.

The number of emerged parasitoids recorded was associated with high reduction caused by treatments, except for Cidial L50\% at 200 and 400 $\mathrm{cm}^{3} / 100 \mathrm{Lwater}$ (4.17 and 4.33 individuals/one cutting, respectively). The number of emerged parasitoids from untreated one cutting was high (34.17 individuals) compared with treated cuttings.

Table (2): Number of dead and alive $P$. scarabaeoides adults after $48 \mathrm{hr}$. of treatment with a rate of 200,300 and $400 \mathrm{~cm}^{3} / 100 \mathrm{~L}$ water under laboratory conditions.

\begin{tabular}{|c|c|c|c|c|c|c|c|c|}
\hline \multirow{3}{*}{ Treatment } & \multicolumn{6}{|c|}{ Concentration } & \multirow{2}{*}{\multicolumn{2}{|c|}{ Total }} \\
\hline & \multicolumn{2}{|c|}{200} & \multicolumn{2}{|c|}{300} & \multicolumn{2}{|c|}{400} & & \\
\hline & Dead & Alive & Dead & Alive & Dead & Alive & Dead & Alive \\
\hline CidialL50\% & 48 & 0 & 30 & 2 & 47 & 4 & 125 & 6 \\
\hline Basodin 60\%EC & 40 & 3 & 55 & 0 & 64 & 2 & 159 & 5 \\
\hline KeitonL50\% & 40 & 2 & 59 & 0 & 60 & 3 & 159 & 5 \\
\hline control & 10 & 2 & 10 & 2 & 10 & 2 & 30 & 6 \\
\hline
\end{tabular}

The number of dead $P$. scarabaeoides adults in maternal galleries after $48 \mathrm{hr}$. of treatment with three tested concentrations (200, 300 and 400 $\mathrm{cm}^{3} / 100 \mathrm{~L}$ water) are shown in table 2 . These numbers were higher for Basodin and Keiton L50\% (159 beetles) than Cidial L50\% (125 beetles) and the least number was in the case of control treatment (30 beetles).

\section{2 - Field experiment}

Table (3): Number of new inside holes and emerged P.scarabaeoides beetles/one cutting under field conditions after treatment. with $300 \mathrm{~cm}^{3} / 100 \mathrm{~L}$ water treatment.

\begin{tabular}{|l|c|c|c|c|c|}
\hline \multirow{2}{*}{ Treatment } & \multicolumn{3}{|c|}{ Inside holes } & Mean no. of emerged beetles \\
\cline { 2 - 6 } & $\begin{array}{c}\text { No/cutting } \\
\text { (prespray) }\end{array}$ & $\begin{array}{c}\text { No/cutting } \\
\text { (2 months after } \\
\text { treatment) }\end{array}$ & $\begin{array}{c}\text { \% } \\
\text { Reduction }\end{array}$ & No./cutting & \% Reduction \\
\hline Cidial L50\% & 14.50 & 19.33 & 38.52 & $581.5 \mathrm{ab}$ & 15.74 \\
Basodin 60\% EC & 13.83 & 24.17 & 19.44 & $477.0 \mathrm{~b}$ & 30.88 \\
Control & 13.83 & 30.00 & - & $690.1 \mathrm{a}$ & - \\
\hline
\end{tabular}

By Handreson and Telton formula (1955).

Fayoum J. Agric. Res. \& Dev., Vol.22, No.2, July, 2008 
Data presented in table (3) showed that Cidial L50\%, and Basodin $60 \%$ EC under field conditions reduced the number of inside holes after two months from treatment to 38.52 and $19.44 \%$, respectively. Cidial L50\% treatment was 2 folds as efficient as that of Basodin $60 \%$ treatment. The total number of emerged beetles decreased insignificantly with treatment being only 15.74 and $30.88 \%$ for Cidial L50\% and Basodin 60\%, respectively.

Results reveled that the application Cidial L insecticide under field conditions was more effective in reducing the number of inside holes of $P$. scarabaeoides due to repellent effect. Whereas Basodin $60 \%$ was more effective in reducing the emergence of beetles causing higher reduction percent due to the mortality of beetles in maternal galleries of olive branches. However, statistical analysis indicated no significant difference between the two tested insecticides (Basodin and Cidial L); both there were significantly different from control.

In this respect, Abdel Rahman, 1995 used two sprays of a mixture of either Cidial L or Basodin or 1 of Actellic, Anthio, Dimethoate or Lebaycid at the end of February and the last week of April, followed by 3 sprays of Actellic, Anthio, Dimethoate or Lebaycid at mid-June, early August and midSeptember gave an effective level of control against all pests attacking olive cultivars. Pena et al. 1998 mentioned that olive logs sprayed with cypermethrin alone or in combination with ethrel, no colonization occurred of $P$. scarabaeoides. Ruano et al. 2008 found that pyrehroid insecticide, Deltamethrin affected the emergence of the bark beetle, with a reduction ranging from $1-13 \%$.

Application of insecticides affected the emergence of parasitoids. This agreed with those results obtained by Mussche et al. 1987, in Tunisia mentioned that during the control of $P$. scarabaeoides hymenoptera knocked down by the insecticide sprays. They indicated that sprays against the wood borers should be applied in September rather than October to protect these parasitoids. On versus the results disagreed with those obtained by Campos and Pena 1997 found that the control of $P$. scarabaeoides by treating cut olive $\operatorname{logs}$ with Methoxychlor at $0.1 \%$, where treatments eliminated part of the pest population and affected the fecundity of exposed females without affecting parasitoids. Also Ruano et al. $\mathbf{2 0 0 8}$ mentioned that the lowest dose employed corresponding to $0.00125 \%$ active ingredient of Deltamethrin reduce emergence of $P$. scarabaeoides without a significant effect on the hymenopteran parasitoids population, except for Cheiropachus quadrum.

In conclusion, it is recommended to use Cidial L50\% or Basodin with concentration $400 \mathrm{~cm}^{3} / 100 \mathrm{~L}$ water in case of severe infestation by the scolytid P. scarabaeoides. Keiton L50\% application is not recommended. Removal of infested branches after pruning as well as the use of the parasitoids as biological control agent are important factors to reduce infestation of the olive pest P. scarabaeoides. 


\section{REFERENCES:}

Abdel- Rahman, A.G. (1995): Seasonal abundance of some pests attacking olives and their control under El-Qasr conditions, Matrouh Governorate. Annals Agric. Sci., Moshtohor. 33 (4): 1553-1564.

Arambourg, Y., (1986): Traite d'entomologie Oleicole. Coaseil Oleicole International. Spain. (c.f. Lozano et al. 1996).

Campos, M. and Lozano, C. (1994): Observations on the reproductive biology of two parasites of Hylesinus varius and Phloeotribus scarabaeoides (Col : Scolytidae): Cheiropachus quadrum (Hym: Pteromalidae) and Dendrosoter protuberans (Hym: Braconidae). Entomophaga 39(1): 51-59.

Campos, M. and Pena, A. (1997): Effect of methoxychlor treatments against Phloeotribus scarabaeoides (Col., Scolytidae) in cut olive logs. Boletin de Sanidad Vegetal, Plagas. 23(2): 263-271. (c.f. CAP abstract)

Handerson, C.F. and Telton, E.W. (1955): Test with acaricides against the brown wheat mite. J. econ, Ent. (48) 157-161.

Ismail, I.I.; Abu-Zeid, N.A. and Abdallah, F.F. (1988): Ecological and behavioral studies on olive tree borers and their parasites. Agric.Res. Rev., 66 (1): 145-152.

Lanari, A. (1980): A practical variation in the control of Phloeotribus scarabaeoides of olive. Informatore Agrario. 36 (9): 9415-9416. (c.f. CAP abstract)

Lozano, C.; Gonzalez, E.; Pena, A; Campos, M.; Plaza, M.T.; Rodriguez, M.; Izquierdo, I. and Tamayo, J. (2000): Response of parasitoids Dendrosoter protuberans and Cheiropachus quadrum to attractants of Phloeotribus scarabaeoides in an olfacttometer. J. Chemical Ecology. 26 (3): 791-799.

Mostafa, F.F.; Hanna, M.A.; Helal, H. and Okil, A.M. (1992): Seasonal fluctuation of the olive bark borer, Phloeotribus scarabaeoides Bern. (Scolytidae, Coleoptera) in Fayoum and the effect of attack density on the biology. Fayoum J. Agric .Res. \& Dev. 6(1): 200-216.

Mussche, G.; Garbous, B.; Bauters, V. and Panis, A. (1987): Preliminary study of the population of Hymenoptera on olive trees in the northwest of Tunisia. Mededelingen- van- de- Faculteit-Landbouwwetens chappen,- Rijks universiteit- Gent. 52 (2a): 303-309. (c.f. CAP abstract)

Mustafa, T. and El-Mazraawi, M. (1996): Attractiveness of different olive branches to the olive bark beetle (neiroun) Phloeotribus scarabaeoides Bern (Coleoptera: Scolytidae). Arab J. plant protect. 14(1): 22-26.

Pena, A.; Lozano, C.; Sanchez- Raya, A.J. and Campos, M. (1998): Ethylene release under field conditions for the management of the olive bark beetle, Phloeotribus scarabaeoides. J. Agric. Entomol. 15 (1): 23-32.

Ruano, F.; Campos, M.; Sanchez- Raya, J. and Pena, A. (2008): Deltamethrin application on colonized olive logs: effect on the emergence of the olive bark beetle Phloeotribus scarabaeoides Bernard 1788 (Coleoptera: Scolytidae) and its associated parasitoids. Crop Protection. 27 (3/5): 614- 621. (c.f. CAP abstract)

Taher, M.M. (1966): Studies on family Scolytidae in the northern coastal region. M.Sc. Thesis, Fac. Agric., Alexandria Univ., 110 pp.

Fayoum J. Agric. Res. \& Dev., Vol.22, No.2, July, 2008 
LABORATORY AND FIELD EVALUATION OF INSECTICIDES... 281

Yatla, A. (1983): Preliminary studies on olive pests and the establishment of their natural enemies in Antalya province. Bitki- Koruma- Bulteni. 23(4): 188- 206. (c.f. CAP abstract).

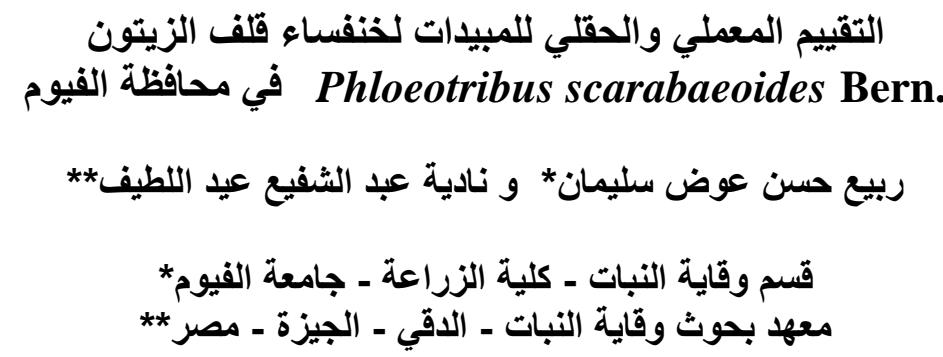

أجريت هذه الدراسة لتقييم بعض المبيدات معملياً وحقلياً على خنفساء قلف الزيتون وقد التها

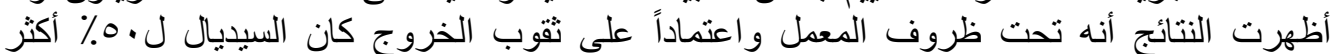

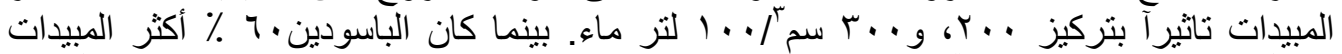

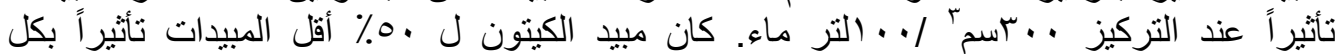

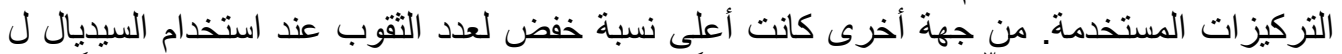

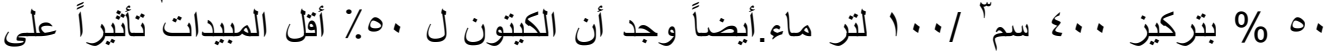

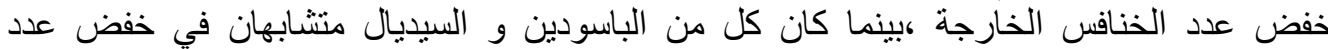

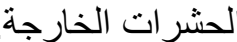

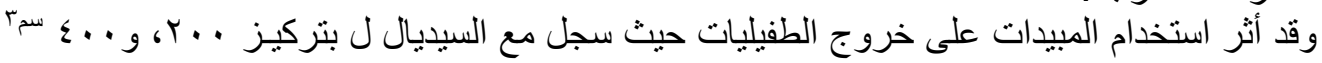

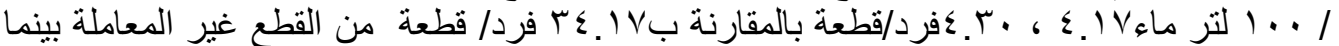
لا توجد طفيليات مع استخدام الباسودين.

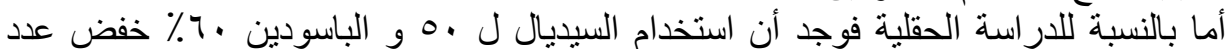

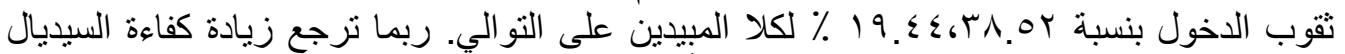

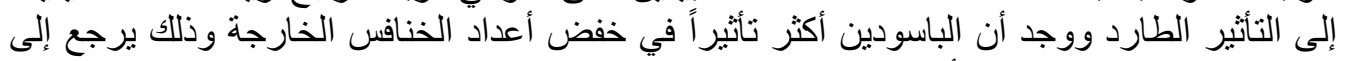

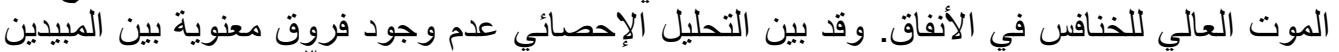

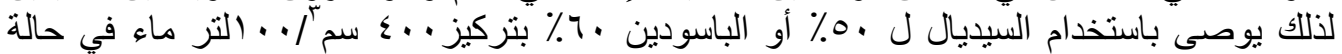
الإصابة الثديدة بخنافس قلف الزيتون.

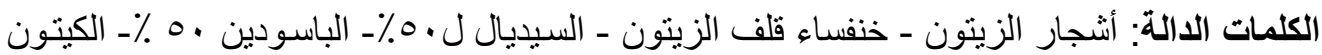

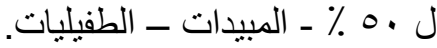

Fayoum J. Agric. Res. \& Dev., Vol.22, No.2, July, 2008 